Александар Новаковић

Универзитет у Нишу

Филозофски факултет

aleksandar.novakovic@filfak.ni.ac.rs
ОРИГИНАЛНИ ИСТРАЖИВАЧКИ РАД

UDK 371.3:811.163.41+821.163.41

DOI: $10.19090 / \mathrm{mv} .2017 .8 .11-30$

\title{
РЕФЛЕКСИВНИ МОДЕЛ МЕТОДИЧКЕ ПРАКСЕ НА ФИЛОЗОФСКОМ ФАКУЛТЕТУ УНИВЕРЗИТЕТА У НИШУ
}

\begin{abstract}
АПСТРАКТ
Рад се бави начином организације и извођења наставне праксе студената на Катедри за српски језик и књижевност на Филозофском факултету Универзитета у Нишу, на коме се са традиционалног прешло на рефлексивни модел стручне праксе. Рефлексивни модел је допринео стварању квалитетнијих наставних кадрова, што спроведено истраживање над 100 студената и показује. Почетна хипотеза да студенти чија је пракса била организована према рефлексивном моделу поседују више особина које чине доброг наставника у односу на оне студенте чија је пракса била организована према традиционалном моделу у потпуности је потврђена.
\end{abstract}

Кључне речи: рефлексивни модел наставне праксе, хоспитовање, Филозофски факултет Ниш, Методичка пракса.

\section{REFLECTIVE MODEL OF METHODICAL PRACTICE AT THE FACULTY OF PHILOSOPHY OF THE UNIVERSITY OF NIŠ}

\begin{abstract}
The paper deals with the way of organizing and realizing the teaching practice of students at the Department of Serbian Language and Literature at the Faculty of Philosophy in Niš, which has been switched from the traditional to reflective model of professional practice. The reflective model has contributed to the education and training of high quality teaching staff, which is shown by a survey with over 100 students. The initial hypothesis was that students whose practice has been organized according to the reflective model have more features that adorn good teachers in comparison to those students whose practice was organized according to the traditional model. This hypothesis has been fully confirmed.
\end{abstract}

Keywords: reflective model of teaching practice, demonstration classes, Faculty of Philosophy in Niš, Methodical practice. 
Такав је 'наш човек', онај прави. Не мисли много ни истрајно. Али чим успе да скрпи некако једну мисао у глави, прва му је брига, не да ту мисао разрађује, проверава и упоређује критички са оним што други људи о истој ствари мисле, него да своју мисао прогласи за једину тачну и једину праву. Срећа је што у нас има доста таквих који су друкчији и који нису прави 'наши људи' (Андрић 1986: 199).

\section{1. УВОД}

Пред наставнике, у школи усмереној на промене, постављају се велика очекивања. Као професионалци морају поступати аутономно, стално унапређујући и употпуњујући своја знања, своје предметне експертизе са педагошким способностима, укључујући и мотивацију за учење, креативност, сарадњу, разумевање социјалног контекста образовања. У таквом настојању ће успети искључиво ако умеју да интегришу принципе доживотног учења у процес извођења наставе, као и истраживањем и унапређивањем сопствене праксе (Максимовић 2011: 111).

О квалитетном образовању наставника се данас, у XXI веку, све више говори и пише, како у академској, тако и у научној заједници. Посебна пажња усмерава се на важност и значај стручне (методичке) праксе студената у оспособљавању за послове и задатке који се од њих очекују. Улога праксе унутар институцијског контекста средишње је подручје у коме се остварује припремање студената за будући професионални живот. Тако се од тридесетих година прошлога века, почевши са Џоном Дјуијем, јављају промишљања о рефлексивном моделу наставне праксе, као једном од најуспешнијих. Своју актуелизацију и широку прихваћеност у оквиру различитих наука и научних дисциплина ова синтагма доживљава од средине осамдесетих година прошлог века, од изласка књиге Доналда Шона Образовање рефлексивног практичара.

Концепт рефлексивног модела наставне праксе заснива се на интердисциплинарности, јединству теорије и праксе, активној улози студента, измењеној комуникацији, образовању кроз кооперацију, али, што је најважније, на самосталном промишљању и критичком приступу студента сопственом раду у школи у оквиру предмета Стручна (методичка) пракса. 
Упознавањем себе и подизањем свести о раду наставника у школском окружењу ствара се могућност преиспитивања вредности и ставова о том подручју деловања студената, будућих наставника.

\section{2. РЕФЛЕКСИВНИ МОДЕЛ НАСТАВНЕ ПРАКСЕ}

Аутори који су се бавили стручном (методичком) праксом наставника имају различите ставове о томе шта би се под њом могло подразумевати. Тако Мехмет Сисман под стручном праксом подразумева два подручја: са једне стране, према његовом мишљењу, стручна пракса обухвата упознавање студената са основама наставног образовања и васпитања пре добијања стеченог звања наставника, док са друге стране, подразумева професионално усавршавање наставника у годинама након завршетка студија (Сисман 2006: 215). Али Госер под стручном праксом подразумева формални и структуирани процес током којег студентинаставници спроводе у дело претходно усвојена знања и вештине, али сада у реалним условима школе (Госер 2013: 139). Припрема будућих наставника пре обављања праксе и контакта с осталим наставницима и ученицима од кључне је важности за успешан рад у школама. Лиск Капел, Леандро Алмеида и Дијана Виера сматрају да је педагошка пракса фаза у којој знање будућег наставника напредује брже и интезивније него у било којој другој фази његовог професионалног развоја (према: Кајрес и сар. 2012: 172). Јернеја Херзог стручну праксу види као поступно и стручно увођење у педагошки рад, чиме се студент, будући наставник, оспособљава за подучавање, а истовремено развија опште и специфичне способности којима ће се у току свога радног века прилагођавати професионалној околини (Херзог 2012: 42).

На методичкој пракси студенти се спремају за улогу креативног, рефлексивног и критички оријентисаног наставника практичара, усвајајући наставне стратегије и методе у планирању и извођењу наставе конкретног предмета у саодносу са осталим организационим јединицама и органима школе. Овако високо постављени исходи стручне наставне праксе у новије време постижу се применом рефлексивног модела, заснованог на менторском облику рада са мањом групом хоспитаната. Другим речима, у Србији се последњих година све више професионална пракса заснива на основама акиионе рефлексије (Јањић и сар. 2014: 13-17). 
Парадигма акционе рефлексије заснована је на критичкој анализи чији је циљ да се студенти развију у практичаре који промишљају делатност на егзактан, објективан, поуздан, валидан и систематичан начин. Познавање теорије и општих принципа, заједно са практичном вештином, и даље су важни циљеви образовања наставника (српског језика), али су у функцији развијања способности тумачења васпитно-образовног процеса. Суштинска одлика будућих наставника треба да буде способност решавања проблема и доношење оптималних одлука у одређеним васпитно-образовним ситуацијама. Она се дефинише у акционом пољу, као способност да се промишљено и одговорно делује. Другим речима, рефлексија се може најшире одредити као промишљање сопствене делатности. У многим развијеним земљама основни циљ професионалног образовања је стварање наставника / васпитача који активно, критички промишља своје професионално искуство. Модел акционе рефлексије супротставља се ставовима да у образовању оних који ће се бавити непосредним васпитнообразовним радом треба да доминира теоријско образовање.

Пожељна професионална пракса је она у којој студент покушава да разуме и примени своја теоријска знања. До таквог разумевања не може се доћи опонашањем ментора, већ критичким односом према постојећем стању и изградњом сопственог педагошког стила. На тај начин ће се формирати критички приступ и студент се неће асимилирати у постојећу, углавном конзервативну, васпитно-образовну средину.

Модел акционе рефлексије подразумева и активно укључивање истраживачког рада у професионалну праксу студената. Учење, истраживање и развој требало би да буду блиско повезани процеси. Сви који се баве непосредним васпитно-образовним радом требало би да учествују у истраживањима. Увођење иновација је најефикасније уколико је спроведено кроз акционо истраживање. Међутим, то није могуће уколико наставници, ментори немају нека основна знања о истраживањима. Осим што су рефлексивни практичари, наставници и васпитачи морају бити и истраживачи сопствене васпитне праксе (Максимовић 2011: 112).

\section{1. Одлике модела рефлексивне наставне праксе}

Иако се прве идеје о конџепту рефлексивности (рефлексивно мишљење и знање) јављају код Дјуија, конструкт рефлексивна пракса везује 
се за Шона. Своју актуелизацију и широку прихваћеност у оквиру различитих наука и научних дисциплина, ова синтагма доживљава од средине осамдесетих година прошлог века. Шонови радови, посебно дело Образовање рефлексивног практичара, сматрају се кључном тачком у процесу пораста значаја идеја о рефлексивном наставнику, односно о рефлексивној наставној пракси (Јањић и сар. 2014: 15). Готово да нема аутора који не полази од Шоновог учења о рефлексивној пракси, без обзира на подручје у коме се она може применити. Наиме, Шон разликује „знање у акцији“ - имплицитно знање које се садржи у интелигентним акцијама и које се тешко вербално експлицира, и „теорије о акцији“ - покушај описа имплицитног знања, на основу посматрања и промишљања (рефлексије). Док је знање у акцији динамично, теорије о акцији (описи радњи, стретегије које користимо, правила, вредности и претпоставки којих се држимо) су статичке и увек су конструкције које се поново у пракси проверавају (евалуација научених теорија и акција на основу саме акције самоевалуација практичара) (Шон 1987: 231-238).

Према Мирјани Шагуд, рефлексивна пракса је „холистички процес који представља начин учења и истраживања у којем се теорија интегрише с рефлексијом (размишљањем) и праксом и у којој рефлексија чини бит процеса учења и мењања“ (Шагуд 2006: 14). Применом рефлексивног модела наставне праксе континуирано врши се преиспитивање знања у пракси, што доводи до усмеравања снаге студената ка развијању стрпљења и објективног сагледавања стварности (Сенге 2003: 20), односно освешћивању личних педагошких ставова и вредности које стоје у основи праксе (Елиот 2007: 15-29). Циљ ове рефлексије је промена у начину на који студентнаставник разуме и интерпретира своју праксу, с једне стране, али и промена саме праксе, с друге стране (Вујисић-Живковић 2007: 243-258).

Многи аутори рефлексивни модел наставне праксе сматрају опозитним традиционалном моделу и позитивистичком приступу образовања практичара (Шон 1987; Брунер 2000; Јањић и сар. 2014), који је заговарао важност теоријских знања будућих наставника. Рефлексивни модел наставне праксе подразумева постојање интелектуалних и вербалних активности којима ученици васпитно-образовног процеса ослушкују једни друге у циљу постизања договора (Винтер 1998: 361-376).

Рефлексивна наставна пракса подразумева размишљања о њој - пре и после активности и деловања током акције. Процес развоја рефлексивног 
практичара значи процес уздизања на метаниво свог васпитног деловања, учења и подучавања (Шагуд 2006: 14). Рефлексивног практичара карактерише рефлексивна отвореност која се јавља када је студент вољан преиспитати властито мишљење и спознати да је било које стајалиште до кога се може доћи у најбољем случају тек хипотеза о свету. Без обзира на то колико била уверљива, без обзира на то колико је студент наклоњен својој замисли, она је увек подложна преиспитивању и побољшању. Кључна тачка у таквом учењу, како наводи Сенге, јесте раскорак између прокламоване теорије (онога што говоримо) и теорије у примени (теорије која је у позадини нашег деловања) (Сенге 2003: 199). Суштина рефлексивног модела је управо у том суочавању са истином о раскораку кроз рефлектовања менталних модела и предрасуда и освешћивање имплицитних теорија.

Појам рефлексивног модела наставне праксе код нас је увела Мирјана Пешић, полазећи од Шоновог разумевања знања у акцији и рефлексије у акцији (према: Марковић 2014: 17). Ауторка рефлексију у акцији дефинише као феномен имплицитног знања које је садржано у практичним акцијама. Појам рефлексије и саморефлексије веже уз искреност и аутентичност, односно разумљивост у групној комуникацији која води еманципацији и мењању праксе (Пешић 2004: 19-30).

Стратегијом развоја образована у Србији до 2020. године, Влада Републике Србије, односно Министарство просвете, науке и технолошког развоја прописало је да програми основних академских студија на департманима за наставни кадар треба да обезбеде стицање свих професионалних компетенција по моделу рефлексивне праксе. Као таква, рефлексивност подразумева коришћење метакогнитивних вештина, креативног и критичког мишљења. С обзиром на то да је реч о процесу који је још увек релативно нов (посебно код нас), а притом и изузетно сложен, јер захтева промене целокупне концепције образовања наставника, он је и релативно спор. Међутим, потреба усавршавања универзитетске наставе наметнула је нашим високошколским установама обавезу да на што ефикаснији и економичнији начин са традиционалног начина извођења наставне праксе пређу на рефлексивни модел који се поставља кроз: формулисање циљева (типа знања и области) и начина образовања за рефлексивну праксу (принципа, стретегија, садржаја, метода и начина организације образовања, улоге учесника у процесу образовања) (Марковић 2014: 27). 
Нови модел наставне праксе заснива се на интегрисању теорије са праксом у којој рефлексија (промишљање) чини суштину процеса учења и мењања кроз преиспитивање и реконструисање имплицитних и експлицитних разумевања ученика, њиховог учења, развоја, васпитања, сопствених васпитачких улога; знања се граде у акцији, кроз рад у школи и подразумева анализу и промишљање својих, али и туђих поступака (поступака својих колега), а рефлексија није само ментална активност, него се проширује и на праксу; искуство се стиче кооперативним учењем, и то не само у оквиру школе, него и стварањем мреже сарадничких установа и организација које саме уче и које се кроз сарадњу и критичко преиспитивање праксе трајно унапређују.

Један од кључних елемената овог начина организовања стручне праксе јесте практиковање, јер кроз њега студенти откривају проблеме који ће бити предмет рефлексије о акцији, развијају рефлексивност у акцији (стичу искуствена знања, доживљаје, интуитивне теорије), проверавају теоријске и искуствене претпоставке и трагају за новим начинима разумевања, у ствари, граде знање (Радуловић 2011: 210).

Говорећи о предмету Интегративна пракса Татјана Марковић јасно истиче постулате рефлексивног модела наставне праксе, те подучавања као целовитог схватања будућег наставника, његове праксе и његовог професионалног образовања (Марковић 2014: 32). Као што је већ речено, истраживањем и критичким промишљањем сопственог деловања у конкретном наставном контексту и сагледавањем своје праксе из различитих перспектива, студенти ће бити у прилици да допринесу сопственом развитку професионалних теорија о васпитно-образовној пракси, као и синтези новог и претходностеченог знања. Другим речима, под рефлексијом би се могла подразумевати освешћена активност, „поглед уназад“, преиспитивање и интерпретација бројних сегмената неке акције: знања, проблема, тока и резултата.

У рефлексивној пракси учење се не догађа само у ,заједништву појединца с праксом", него и с другим субјектима. Тимски рад је начин спровођења рефлексивне праксе. Реч је о процесу усклађивања и развијања способности тима да креира резултате које његови чланови заиста желе, а према заједничкој визији (Марковић 2014: 32). Тимски рад обезбеђује психолошку сигурност код студената, води ка развијању социјалних компетенција које настају у интеракцији индивидуалних и социјалних 
чинилаца, и могу се означити и као квалитети и као вештине. Тимским радом студенти се оспособљавају за преиспитивање сопствених разумевања и разумевања других, што је добар начин за обогаћивање властитог разумевања одређених појава и проблема, расправљање о њима и њихову реконструкцију. Маргарет Витли истиче да „ми најбоље учимо у односу са колегама са којима делимо заједничку праксу" (Витли 2005: 11). Из угла акционе рефлексије добра је она пракса у којој студент покушава да разуме и примени своја теоријска знања, прати и анализира своје искуство (и искуство својих колега) и из њега учи (Николић 2008: 165-175).

\section{3. ОРГАНИЗАЦИЈА СТРУЧНЕ ПРАКСЕ НА ФИЛОЗОФСКОМ ФАКУЛТЕТУ У НИШУ}

Филозофски факултет Универзитета у Нишу има два акредитована студијска програма основних академских студија Србистике. Обема студијским програмима прописано је извођење Стручне (методичке) праксе у летњем семестру завршне године студија, јер се тиме поштују начела поступности и примерености у настави.

У току четврте године студенти се обавезним и изборним предметима припремају за извођење стручне праксе, а касније се упућују на хоспитовање у основну и средњу школу. Из године у годину се у начин извођења и организовања стручне праксе уносе измене, како би студентима било омогућено стицање квалитетнијих знања, која су у вези са наставничком професијом.

Ранијих година студенти су били у обавези да у основној и средњој школи опсервирају и одрже по 4 часа у одабраним школама на територији Ниша или на територији градова из којих потичу. О тим опсервираним и одржаним часовима водили су дневник праксе, који је био услов за излазак на испитне часове - асистент је утврђивао њихов квалитет, и уколико би дневник праксе испуњавао одређене критеријуме, студент би се упућивао на испитне часове; тако су студенти полагали два испитна часа (први у основној из области граматике и други из области књижевности у средњој школи).

Међутим, пракса је показала одређене недостатке. Наиме, студенти су за обављање свога хоспитовања бирали школе у местима из којих потичу или школе које су похађали. Познајући предметне професоре српскога 
језика, често су своје предиспитне обавезе завршавали и пре него што би заправо оне и почеле - на основу познанства узимали су потврде о завршеном хоспитовању. Што се тиче дневника праксе, често би се служили дневницима својих претходника или једноставно их везивали за измишљене часове, тј. часове за које је било најлакше написати припрему за час и пропратне коментаре (уколико би ти часови били они које су „опсервирали“). Све то је доводило до тога да студенти на испитним часовима пред предметним професором не покажу задовољавајући ниво знања и наставничких компентенција за добијање позитивне оцене на испиту.

Потреба за сталним усавршавањем универзитетске наставе утицала је на то да поменути недостаци буду отклоњени, а универзитетска настава учињена квалитетнијом и привлачнијом за будуће студенте основних академских студија србистике. Захваљујући великом залагању и изузетним напорима професора др Марине Јањић, предметног професора методичке групе предмета, и руководства Филозофског факултета на челу са проф. др Гораном Максимовићем, за само две године Стручна (методичка) пракса је у погледу организовања и извођења показала видан напредак. У вези са тим, прешло се на рефлексивни модел, о коме је више речи било у претходном поглављу.

Све предности организовања стручне праксе према рефлексивном моделу први су у правој мери осетили студенти који су основне академске студије србистике уписали 2011/12. академске године. Знатне измене у организацији и извођењу стручне праксе допринеле су постизању квалитетнијих наставничких знања и вештина код студената четврте године Филозофског факултета Универзитета у Нишу.

У реорганизацију процеса стручне праксе кренуло се од њених основних поставки. За разлику од претходних генерација, нове генерације студената србистике своје хоспитовање обављају у школама на територији града Ниша. У договору са асистентом студенти се организују у групе од по четири или пет чланова; студенти добијају по једну основну и средњу школу у којима опсервирају по четири часа и одрже у паровима по два часа; притом се води рачуна да подједнако буду заступљени часови језика и књижевности - студенти опсервирају по два часа из језика и књижевности, односно, држе у паровима по један час из језика и по један из књижевности, како у основној, тако и у средњој школи. Уместо дневника праксе, који је 
писан без одређене форме, студенти користе Практикум за реализаиију професионалне наставне праксе професора др Марине Јањић и њених сарадника, уз помоћ кога предметни професор и његов асистент могу континуирано пратити индивидуалан рад студената. Од изузетне важности у извођењу наставне праксе је и обавеза студента да се јави асистенту задуженом за методичку праксу, како би у разговору биле откривене позитивне или негативне стране опсервираних и одржаних часова, односно разменила искуства, што су главне карактеристике рефлексивног модела наставне праксе. Свакодневним радом у школи и на факултету, студент усавршава своје наставничке компетенције, односно активно се припрема за свој наставнички позив. Када испуни све своје предиспитне обавезе и уредно попуни практикум, студент стиче право да изађе на два испитна часа - први у основној школи (обично из области граматике) и други у средњој школи (из области књижевности). На тај начин студент бива адекватно оцењен за свој рад и труд у испуњавању предиспитних обавеза и полагању испитних часова.

\section{1. Практикум за реализацију професионалне наставне праксе}

Практикумом за реализаиију професионалне наставне праксе (са студентским портфолиом) Марина Јањић, Јелена Максимовић, Гордана Ђигић и Снежана Божић учиниле су огроман корак ка организовању квалитетније наставне праксе, што су резултати добијени истраживањем јасно показали. Преузимајући функцију дневника праксе, Практикум је допринео олакшању организовања и извођења стручне праксе.

Практикум се састоји из три дела, који доприносе не само побољшању у њеном организовању и извођењу, него и утврђивању и проширивању теоријских знања студената. Тако је читав први део Водич праксе намењен упознавању студената са значајем рефлексивног модела наставне праксе у њеном унапређивању, као и са психолошким основама наставног проиеса и иновативним моделима наставе.

Други део Практикума уједно је и најважнији за извођење методичке праксе. Студенти се детаљно упућују у организационе облике рефлексивног модела наставне праксе. Почев од табеле активности студената на професионалној пракси, преко бланко образаца за посматрање часова, долази се до бележака и образаца за писање припреме за час, које 
представљају кључни део рада студената на наставној пракси, на основу кога ће студенти касније бити и оцењени. У белешкама о опсервираним часовима, као и завршним белешкама, студенти бележе своја размишљања о часовима, откривајући позитивне и негативне стране рада у конкретним наставним ситуацијама. За белешкама следе бланко обрасци припрема за час (њих 8), које студенти попуњавају, водећи притом рачуна да и за оне часове које су опсервирали напишу сопствене сценарије за час, отклањајући уочене недостатке и пропусте рада својих ментора. Осим што ће од ментора из својих школа добити оцене за труд, рад и сналажење у конкретним наставним ситуацијама током наставне праксе, студенти ће оценити и сопствено залагање и квалитет рада у евалуативном листу за студенте.

Трећи део доноси прилоге међу којима се налазе најважнија документа и правна акта у области образовања, односно веб-адресе на којима се могу наћи. Између осталих, ту се могу наћи закони о основама система образовања и васпитања, наставни планови и програми, стандарди постигнућа у образовању, Стратегија образовања у Републици Србији до 2020. године и тако даље.

Уредно попуњен Практикум неопходан је услов за полагање испитних часова. У случају да практикум не буде на задовољавајући начин попуњен, асистент га враћа студенту на дораду, након чега студент стиче пуно право да изађе на испитне часове, које у договору са студентом заказује асистент у школама у којима је завршен процес хоспитовања.

\section{4. МЕТОДОЛОШКЕ ПОСТАВКЕ ИСТРАЖИВАҢА}

\section{1. Предмет истраживања}

Током процеса хоспитовања студент-наставник се ставља у ситуацију да своја претходно стечена знања и вештине примени у школском окружењу и развије их у складу са очекиваним професионалним компетенцијама. Стручна (методичка) пракса подразумева учешће у испуњавању одређених задатака, едукацији, вежбању, као и извршавању ванкурикуралних активности. Са колико ће успеха реализовати стручну (методичку) праксу пре свега зависи од стечених лингвистичких и књижевних компетенција, као и благовремене припреме на часовима методичких предмета. Стога је од изузетне важности спроводити 
истраживања међу студентима која ће показати да ли универзитетска настава, таква каква је, позитивно делује на развијање квалитетних наставничких компетенција. У том смислу, неопходно је утврдити да ли су студенти довољно спремни за подучавање будућих нараштаја.

Такође, стално се мора водити рачуна о ставу студената о важности наставне праксе, односно проблемима и потешкоћама са којима су се сусретали током њене реализације. Да би се то открило, у истраживању су постављена два примарна задатка:

- Испитати мишљења студената о томе да ли су њихова претходна знања олакшала реализацију стручне праксе, и

- Испитати да ли су студенти чија је пракса организована према рефлексивном моделу наставне праксе стекли квалитетније наставничке компетенције од оних чија је пракса била организована према традиционалном моделу.

Како се последње године на Филозофском факултету у Нишу активно примењује рефлексивни модел организовања и извођења стручне праксе, аутор овога рада посебну пажњу посвећује утврђивању разлике између традиционалног и новопримењеног модела у погледу формирања и јачања наставничких компетенција код студената, будућих наставника и професора српскога језика.

\section{2. Значај истраживања}

Стручна (методичка) пракса на Филозофском факултету у Нишу, на студијском програму основних академских студија србистике, заузима значајно место, јер се захваљујући њеној квалитетној организацији и реализацији студенти на јединствен и поступан начин уводе у практичан рад наставника и професора српскога језика.

Полазећи од чињенице да су високообразовне институције у којима се образују будући наставници, као и студијски програми на којима је утемељено образовање будућих наставника изложени сталним проверама и критикама, неопходно је континуирано пратити и усавршавати курикулуме лингвистичких и књижевних предмета који пружају студентима довољно научних компетенција за рад у школама и на факултетима. Од још веће важности је и стална контрола и оцена спровођења стручне (методичке) 
праксе, како би се из године у годину она побољшавала и усавршавала. Једино се њеним константним вредовањем могу постићи завидни резултати у формирању будућих наставничких кадрова. Стога је ово истраживање само прво у низу оних која треба да пруже одговор на питање колико је наставна пракса добро организована и извођена на Филозофском факултету Универзитета у Нишу, на Катедри за српски језик и књижевност.

\section{3. Хипотеза истраживања}

На основу одређеног проблема, дефинисаног предмета и значаја истраживања, наша хипотеза гласи:

Студенти чија је Стручна (методичка) пракса била организована према постулатима рефлексивног модела поседују квалитетније наставничке компетенције од својих колега чија је пракса била организована на традиционалан начин.

\section{4. Методологија истраживања}

Када је у питању експериментална процедура, испитивање става студената о важности стручне (методичке) праксе врши се методом дескриптивне анализе, у оквиру квалитативних истраживања која пружају могућност предметним професорима да анализирају рад и размишљања својих студената. Притом, квалитативна истраживања као што су опсервација и анкетирање омогућавају уочавање позитивних страна студентских запажања и утисака.

У истраживању је коришћена техника анкетирања, а за главни иструмент одабран је упитник. С обзиром на то да не постоје стандардизовани инструменти у овој области и с обзиром на природу истраживачког проблема, за ову прилику конструисан је Упитник за студенте. Упитник је анонимног карактера и састоји се из два дела; први део чине питања која се односе на основне податке о испитанику, док се други део састоји из питања којима се желео проверити став студената о организовању и извођењу стручне праксе на Филозофском факултету у Нишу. Пре сваког питања налази се јасно формулисан задатак. Попуњавање упитника није временски ограничено, јер су свршени студенти упитник попуњавали у електронској форми, чији су резултати на исти начин прикупљени. 
Анализа добијених резултата извршена је уз помоћ статистичке обраде података, односно коришћењем софтверског пакета SPSS 20.0.

\section{5. Корпус истраживања}

За ово истраживање изабран је намерни узорак. Учешће у истраживању узели су свршени студенти основних академских студија србистике (и, наравно, апсолвенти који су завршили процес хоспитовања) Филозофског факултета у Нишу. У складу са почетном хипотезом, међу испитаницима су се нашле две популације студената - студенти чија је методичка пракса била организована према постулатима рефлексивног модела и студенти чија методичка пракса била организована на традиционалан начин. Укупно је испитано 100 студената, по педесет њих из обе наведене групације.

\section{5. АНАЛИЗА РЕЗУЛТАТА ИСТРАЖИВАЊА}

У анализу добијених резултата истраживања кренуло се од питања која се тичу организације основних академских студија србистике, распореда методичке групе предмета, односно организације Методичке праксе. На питање Сматрате ли да Филозофски факултет Универзитета у Нишу на Катедри за српски језик и книжевност пружа довољно компетенција (лингвистичких и књижевних) за рад у школи? 53\% испитаних студената је одговорило позитивно, $43 \%$ делимично и само $4 \%$ је одговорило да овај факултет не пружа довољно компетенција за рад у школи.

Сви анкетирани студенти су се позитивно изјаснили на питање Да ли сматрате да је стручна (методичка) пракса значајна за Ваш будући педагошки рад? Овај податак је од изузетне важности, јер показује да су студенти препознали значај стручне праксе за сопствено професионално усавршавање и припремање за рад у школи.

Студенти чија је пракса била организована на традиционалан начин највише замерки упутили су на распоред методичке групе предмета, јер сматрају да је свих пет методичких предмета (што обавезних, што изборних) смештено у два семестра и притом наставну праксу похађају без одслушаних предавања из Методике наставе књижевности. Међутим, и 
одговори генерације студената представника рефлексивног модела наставне праксе нису се разликовали - чак 94\% представника традиционалног модела наставне праксе и 41\% представника рефлексивног модела изразило је потребу реакредитације студијског програма, што је већ и учињено 2014. године. Према новом акредитованом програму, будући студенти србистике ће обавезне и изборне методичке предмете слушати и похађати у току четири семестра, тако да ће обавезне испите (Увод у методику и методика наставе српског језика и Методика наставе књижевности) полагати у првом семестру треће, односно четврте године, а Методичку праксу у другом семестру четврте године. И поред одређених замерки на распоред методичке групе предмета, 91\% студената сматра да су стечена лингвистичка, књижевна и методичка знања у складу са захтевима предмета Методичка пракса, а самим тим и с наставним ситуацијама са којима he ce сусрести на хоспитовању и приликом будућег рада.

Реализованим истраживањем у потпуности је потврђена почетна хипотеза да студенти чија је Стручна (методичка) пракса била организована према постулатима рефлексивног модела поседују квалитетније наставничке компетенције од својих колега чија је пракса била организована на традиционалан начин, те се још једном потврдило да рефлексивни модел доприноси постизању одличних резултата у процесу обучавања студената за обављање наставничког позива. Уз то, добијени резултати су показали да су студенти чија је пракса била организована према постулатима рефлексивног модела, задовољнији начином организовања и извођења наставне праксе од својих колега чија је пракса организована на традиционалан начин. Добијени су обрнуто пропорционални резултати - 39 (или 78\%) студената чија је пракса била организована према рефлексивном моделу одговорило је позитивно на питање $У$ којој мери сте задовољни начином организащије и спровођења наставне праксе на Катедри за српски језик и књижевност?, док су сасвим супротно одговорили студенти друге посматране групације $(74 \%$ испитаника се негативно изјаснило на постављено питање), сматрајући да постоји много недостатака у организацији и извођењу стручне праксе на Филозофском факултету Универзитета у Нишу.

Након потврђивања почетне хипотезе као логично питање може се поставити: Зашто студенти представниции традиционалног модела наставне праксе показују незадовољство у вези са предметом? Одговор је 
више него јасан - у складу са теоријом о недостацима традиционалног модела и предностима које доноси рефлексивни модел наставне праксе да се закључити да организација и начин њеног извођења играју велику улогу у формирању ставова студената. Тако, непостојање сарадње и међусобне комуникације са асистентом, може бити један од главних разлога незадовољства студената, пошто је $84 \%$ студената преставника традиционалног модела рекло да није било сарадње са асистентом у току спровођења методичке праксе. Даље, непостојање тимског рада и хоспитовања, сарадње међу члановима тима и посматрање дневника праксе само као предиспитне обавезе разлози су због којих студенти представници традиционалног модела показују незадовољство у погледу организације и извођења методичке праксе. Са друге стране, обезбеђујући све наведене услове, рефлексивни модел знатно доприноси задовољству студената методичком праксом. Помена ради, док 54\% студената представника традиционалног модела дневник праксе сматра само предиспитном обавезом, дотле чак 68\% студената представника рефлексивног модела попуњавање практикума види као прилику да критички сагледа свој рад на методичкој пракси.

Ипак, и поред свих предности које доноси рефлексивни модел наставне праксе, организација исте може утицати на квалитет њеног спровођења. Наиме, на питањима отвореног типа студенти су могли да изнесу своје виђење проблема са којима су се сусретали током хоспитовања, независно од примењеног модела. Чак 68\% студената се изјаснило да је имало потешкоћа приликом писања припрема за часове. У вези са тим, и пре спроведеног истраживања из штампе је изашао приручник аутора Марине Јањић и Александра Новаковића под називом Наставно дизајнирање часова српског језика, који ће студентима бити од велике помоћи приликом писања припрема за час. Аутори су у свакодневном раду са студентима осетили потребу за писањем оваквог уџбеника.

Затим, студенти истичу постојање јаза између теорије са којом се срећу на часовима методика и праксе са којом се упознају у школама - пре свега се разлика односи на то што у школама нема идеалних услова под којима се на часовима теорије претпоставља да ће се настава изводити, а такође су студенти истакли и недовољну опремљеност школа савременим наставним средствима, те немогућности реализације игролике наставе. 
Чак 75\% испитаних студената је као проблем постојања расцепа између теорије и праксе навело недовољну обученост ментора за овај посао, jep је приметно њихово удаљавање од савремених токова методичке науке, што изискује потребу организовања честих менторских обука са различитим садржајима, које би поправиле наведену ситуацију. Осим тога, студенти примећују недостатак познавања законских прописа у вези са правима и обавезама наставника у школама.

Све претходно речено је утицало на то да $61 \%$ студената Методичку праксу види (по „тежини“) као равноправан предмет осталим. Од изузетне важности је податак да би $88 \%$ анкетираних студената променило начин извођења наставне праксе у том смеру да студенти-хоспитанти у школама имају прилику да држе више часова индивидуално. То указује на чињеницу да су студенти, без обзира на примењени модел, препознали значај и важност стручне праксе за сопствени будући педагошки рад.

\section{6. ЗАКЉУЧАК}

Предуслов за квалитетан наставни процес јесу професионално оспособљени наставници. Данас, у времену које карактеришу брзе и честе промене, овај захтев постаје важнији, него што је то био случај у прошлости. Осим тога, улога наставника (српског језика) добија на комплексности (Јањић, Новаковић 2015: 7), те је од изузетне важности оспособљавање студената за решавање задатака и превазилажење проблема у разноврсним наставним ситуацијама. Квалитетнији наставни кадрови могу се добити једино уз помоћ правилно организоване и извођење Методичке (стручне) праксе.

Анализом научне литературе која се бави питањем методичке праксе може се закључити да је пажња аутора последњих двадесетак година усмерена на примену рефлексивног модела, који се темељи на учењу кроз рефлексије, размени са колегама из тима, предметним професорима и менторима и развоју нових идеја и прилагођавању новим ситуацијама и различитостима. Модел рефлексивне праксе се примењује у свим развијенијим земљама Европе, почев од Финске, преко Норвешке, Данске, Русије, Немачке, до Словеније. Наравно, у складу са намером евроинтеграција Република Србија је Стратегијом развоја образовања до 2020. године проверени модел организације и извођења стручне праксе 
имплементирала у високошколски образовни систем. Међутим, како процес имплементације није једноставан, неопходна су стална истраживања која ће довести до квалитетније реализације методичке праксе.

Филозофски факултет Универзитета у Нишу показује изузетан напредак у погледу организације и извођења методичке праксе. У кратком временском периоду се са традиционалног модела прешло на рефлексивни модел, који је допринео чињењу значајних помака у оспособљавању будућих кадрова. Истраживање је показало да студенти чија је пракса била реализована према рефлексивном моделупоседују квалитетније наставничке компетенције;уз то,задовољнији су начином њене организације и извођења, него што је то случај са студентима представницима традиционалног модела. Наиме, 39 (или 78\%) студената чија је пракса била организована према рефлексивном моделу је одговорило позитивно на питање $У$ којој мери сте задовољни начином организачије и спровођења наставне праксе на Катедри за српски језик и књижевност?, док су сасвим супротно одговорили студенти друге посматране групације (74\% испитаника се негативно изјаснило на постављено питање), сматрајући да постоји много недостатака у организацији и извођењу стручне праксе на Филозофском факултету Универзитета у Нишу.

Ипак, и поред запажених резултата које је донела примена рефлексивног модела, студенти су мишљења да би одређене промене у њеној организацији на Филозофском факултету само донеле бољитак будућим генерацијама. У том смислу, студенти предлажу продужење трајања Стручне праксе на два или чак три семестра, што ће омогућити више школских часова на којима ће развијати своје наставничке компетенције. Стога је од изузетне важности стално пратити, анализирати и унапређивати организацију и њено извођење, како би се из године у годину школовали квалитетнији наставни кадрови.

\section{ЛИТЕРАТУРА}

Andrić, I. (1986). Znakovi pored puta. Sarajevo: Svjetlost. Bruner, DŽ. (2000). Kultura obrazovanja. Zagreb: Eduka.

Budić, S. i sar. (2008). Didaktičko-metodički aspekti studentske prakse u partnerskim relacijama fakulteta $i$ škola. Novi Sad: Filozofski fakultet.

Valenčić Zuljan, M., Cotič, M., Fošnarič, S., Peklaj, C., Vogrinc, J. (2011). “Teacher education in Slovenia“. European Dimensions of Teacher Education Similarities and Differences. Ljubljana: Faculty of Education. 
Вујисић-Живковић, Н. (2007). "Педагошка истраживања и образовање наставника“. Зборник Института за педагошка истраживања, Београд, 39 (2), 243-258.

Winter, R. (1998). "Managers, Spectators and Citizens: where does theory come from action research". Educational Action Research, 6 (3), 361-376.

Wheatley, M. (2005). Zajednice prakse - potpora novim liderima. Novem d.o.o.

Göçer, A. (2013). "Teacher Educator's and Guidance. Teachers' Evaluation of Student. Teachers' Teaching Practice (A Qualitative Study) ". Croatian Journal of Education. Vol:15; Sp. Ed. No. 3/2013. 125-147.

Elliott, J. (2007). Reflecting Where the Action Is: The Selected Writings of John Elliott on Pedagogy and Action Research, London: Routledge.

Закон о основама система образовања и васпитања, Службени гласник Републике Србије, бр. 72/2009.

Јањић, М., Максимовић, Ј., Ђигић, Г., Божић, С. (2014). Практикум за реализащију професионалне наставне праксе. Ниш: Филозофски факултет.

Јањић, М., Новаковић, А. (2015). Наставно дизајнирање часова српског језика. Ниш: Филозофски факултет.

Caires, S., Almeida, L., \& Vieira, D. (2012). "Becoming a teacher: student teachers experiences and perceptions about teaching practice". European Journal of Teacher Education, 35 (2). 163-178.

Максимовић, J. (2011): “Ставови наставника према истраживању васпитнообразовне праксе у школи“. Радови Филозофског факултета, број 13, књига 2. Пале: Филозофски факултет Универзитета у Источном Сарајеву. $111-125$.

Marković, T. (2014). Model integrativne prakse u inicijalnom obrazovanju vaspitača. Odbranjena doktorska disertacija na Filozofskom fakultetu Unvierziteta $\mathrm{u}$ Beogradu. Beograd: Filozofski fakultet.

Николић, Р. (2008). Пракса студената у функцији оспособљавања за учитељьки позив. Зборник радова, 10.Ужице: Учитељски факултет. стр. 165-175.

Pešić, M. (2004). Pedagogija u akciji (Metodološki priručnik). Beograd: Institut za pedagogiju i andragogiju.

Правилник о наставној пракси студената Филозофског факултета у Нишу (2012). Ниш: Филозофски факултет.

Radulović, L. (2011). Obrazovanje nastavnika za refleksivnu praksu.Beograd: Filozofski fakultet.

Rajović, V., Radulović, L. (2007). "Kako nastavnici opažaju svoje inicijalno obrazovanje: na koji način su sticali znanja i razvijali kompetencije“. Nastava $i$ vaspitanje Časopis za pedagošku teoriju i praksu, br. 4. str. 413-434. Beograd: Pedagoško društvo Srbije.

Schön, D. (1987). Educatin the reflective practitioner: Toward a new design for teaching and learning in the professions, San Francisco, Oxford: Jossey-Bass.

Senge, R. M. (2003). Peta disciplina-principi i praksa učeće organizacije.Zagreb, Mozaik knjiga.

Şişman, M. (2006). Introduction to Science of Education (2nd Ed.). Ankara: Pegem A Publication. 
Стратегија развоја образовања у Србији до 2020. године, Београд: Службени гласник РС, 107/2012-12.

Herzog, J., Grmek, I. M., Čagran, B. (2012). „Pogledi mentora na pedagošku praksu studenata razredne nastave“. Hrvatski časopis za odgoj i obrazovanje, Zagreb: Učiteljski fakultet Sveučilišta u Zagrebu, 14 (1), 25-47.

Šagud, M. (2006). Odgajatelj kao refleksivni praktičar. Petrinja: Visoka učiteljska škola u Petrinji.

\section{Aleksandar Novaković \\ REFLECTIVE MODEL OF METHODICAL PRACTICE AT THE FACULTY OF PHILOSOPHY OF THE UNIVERSITY OF NIŠ}

\section{Summary}

The paper deals with the way of organizing and realizing the teaching practice of students at the Department of Serbian Language and Literature at the Faculty of Philosophy in Niš, which has has been switched from the traditional to reflective model of professional practice. The reflective model has contributed to the education and training of high quality teaching staff, which was shown by a survey with over 100 students. Students whose practice has been organized according to the reflective model have more features that adorn good teachers in comparison to those students whose practice was organized according to the traditional model. This was the initial hypothesis and it has been fully confirmed. In addition to this, the first group of students was more pleased with the organization and performance of the practice. Namely, 39 (or 78\%) of students whose practice has been organized according to the reflective model has responded positively to the question: How satisfied are you with the way of organization and implementation of the teaching practice at the Department of Serbian Language and Literature? Students from other observation groups responded the opposite ( $74 \%$ of respondents answered the question negatively), noting that there were many shortcomings in the organization and implementation of the professional practice at the Faculty of Philosophy in Niš.

Keywords: reflective model of teaching practice, demonstration classes, Faculty of Philosophy in Niš, Methodical practice. 